\title{
CORPORATE UNIVERSITY AS A FORM OF EMPLOYEE TRAINING AND DEVELOPMENT IN AMERICAN COMPANIES
}

\author{
Iryna Lytovchenko \\ National Technical University of Ukraine "Kyiv Polytechnic Institute”, Kyiv, Ukraine \\ irinalyt@ukr.net
}

\begin{abstract}
The article deals with the problem of corporate university as a form of employee training and development in American companies. Corporate training plays a leading role in the successful operation of US companies and is a factor of their competitiveness and efficiency in the marketplace. Corporate university is an advanced form of organizational training which emerged in response to the challenges of the information society and the global economy, increased competition in the market, the failure of the traditional institutions of professional education to meet the needs of the modern economy for highly qualified employees. Modern corporate university is a system of organizational development and personnel training, united with a single concept and methodology, inextricably linked and coordinated with the strategies of the organization. The main functions of the corporate university are training of various levels of company employees, knowledge management, formation of common corporate values, development of corporate culture, promotion of innovation. Since organizations have different needs and development strategies, corporate universities of different companies in the United States differ in purpose, objectives, structural characteristics, methods of instruction. The learning process in the corporate university has andragogical focus and is characterized by extensive use of e-learning technologies.
\end{abstract}

Keywords: corporate training; workplace learning; training departments; corporate university; learning process; e-learning; the USA.

Introduction. The transition to the information society and global economy, increased competition in the market at present pose new challenges both to professional education which must meet the needs of the modern economy and to organizations which must take the initiative in training their employees and strengthen links with education and science. Training personnel in rapidly developing, complex, variable, dynamic business world requires a new educational paradigm. As a result, corporate university arises as an advanced form of learning in an organization that to the fullest extent embodies the convergence of business and education as also focuses on personnel training and development aimed at meeting the needs of the company.

Given the complexity and expensiveness, this form of corporate education in Ukraine is only at an early stage of development, thus, the study of the progressive experience of foreign countries, especially the United States, where corporate universities emerged first in the world and have gained a high level of development, is particularly useful and relevant.

The problem of corporate education was the subject of interdisciplinary research of scholars in different fields: economics, management and marketing (C. Argyris, J. Brown, R. Cyert, G. Duguid, P. Huber, J. March, R. Nelson, I. Nonaka, P. Senge, S. Winter), education (V. Zaryhin, R. Silkin, V. Skarha), psychology (O. Dubinenkova, V. Soroka, P. Trifonova), sociology (Y. Karaman, T. Radayev) and others. Features of corporate university have been studied in works of M. Allen, J. Meister, M. Rademakers, P. Jarvis, R. Dealtry, J. Côté, A. Allahar and others, but organizational and functional aspects of its development in the United States need further analysis.

In this regard, the purpose of our research was determination of the organizational and functional characteristics of corporate university as the most advanced form of corporate education in the US, including identification of the main factors of emergence and development of this educational institution, its conceptual features, modes, characteristics of the learning process.

From the methodological perspective, the research was based on interdisciplinary and systematic approaches. Thus, we used a set of interrelated research methods: comparative, structural, systemic-functional analysis, comparison and synthesis, which are appropriate for studying scientific works, official documents, empirical data.

Corporate training as a factor of increasing the efficiency of the company. Corporate training emerged in the early twentieth century as a result of the evolution of apprenticeship, the oldest and most traditional form of vocational training in the United States (Lytovchenko, 2015). It 
marked the implementation of a new concept of workplace learning, which had its philosophical foundations, programs, educational technologies, the system of delivery and organizational structure.

In the context of globalization and internationalization of economic relations, the creation of a single global socio-educational space, corporate training is a necessary prerequisite of companies' competitiveness. According to researchers (Petrjakov \& Pevzner, 2009), corporate training is a process of interaction between those who teach and those who learn, organized in the interests of the company and its staff, aimed at professional development of employees and taking place both within and outside the company. However, corporate training is also perceived as a form of further training, professional improvement and development of knowledge and skills of workers within an organization to ensure the successful and effective implementation of its strategic objectives and the increase in its efficiency (Nasibullin, 2011).

It should be emphasized that the implementation of corporate training in the company addresses a range of problems, including improvement of the efficiency of the company; preparation for changes, which presupposes the involvement of staff in innovation processes; formation of common corporate values and corporate culture; generation of ideas, finding ingenious managerial and economic decisions; stimulation of innovative development of the company, etc. (Korablinova \& Stepanenko, 2014).

Corporate training has certain distinctive features, including proactive nature of the content and methods of training; increase in employees' motivation with regard to possibilities of professional growth and development; continuity in the acquisition of professional competencies; adaptability to rapid changes in society, science and technology; practical orientation in accordance with the requirements and needs of the company; innovativeness of forms, methods, technologies of learning; focus on the development of the company.

The results the study show that corporate training is widely used in the following institutional forms:

1) workplace learning;

2) training departments;

3) corporate universities.

Workplace learning is the simplest form of personnel training. It is used for employees who learn a job directly by doing it. This form of learning is aimed at the development of certain skills and takes place in a real manufacturing environment, with the use of the facilities of the enterprise. Hence, the benefits of workplace learning are its practical orientation, provision of possibilities for employees to acquire and develop skills in the real work environment. However, a significant drawback of workplace learning is its non-systemic character and spontaneity. Therefore, workplace learning can unlikely be considered a system of continuous vocational training.

On the other hand, there is a widespread L \& D "70-20-10" Model which proves the importance of workplace learning. For example, the MARS Company prefers it in preparing not only linear but also top managers. According to this model, $70 \%$ of time is spent on solving real workplace problems; $20 \%$ of the time - on workplace learning under the supervision of an experienced colleague with the use of apprenticeship, coaching, mentoring, tutoring, etc. $10 \%$ of the time is used for classroom training: workshops, trainings, etc. "70-20-10" Model is used by both large corporations and small companies (Cross, 2011).

The study of corporate training departments showed that they are transmitters of uniform standards of training, but perform narrow specialized functions of the development of professional skills of certain groups of workers in response to situational demands and the current problems of the corporation. They are oriented to solving tactical problems of the company; they can employ both full-time and invited trainers.

Unlike corporate training departments which are in fact educational divisions of the companies, corporate universities are separate strategic business units of the corporations. Their task is not only further training of employees and development of some of their skills but also improvement of the staff efficiency aimed at the achievement of the company's strategic goals, ensuring its competitiveness. The corporate university contributes to the process of continuous improvement in the management of the corporation and its development as a whole. 
Factors of emergence and spread of corporate universities in the US. Corporate universities in the US emerged in the 1920's. The first institution of this kind was General Motors Engineering and Management Institute (1919), now - Kettering University. At first, it was aimed at training sales professionals (The School of Automobile Trades). Nowadays the university provides programs in MBA, production management, engineering, lean production and others.

Further development of corporate universities intensified in the 1950s, when Disney University, General Electric University and others were founded. An important milestone in the development of corporate universities in the US was the emergence of McDonald's corporate university in 1961. Today, not only the majority of big US corporations have their corporate universities, but also medium-sized companies initiated the establishment of new educational projects called corporate universities, academies, institutes and schools. Thus, about eighty percent of the Fortune 500 companies (largest industrial companies in the US annually selected by Fortune magazine according to the value of annual income) either have corporate universities or are planning to establish ones (Nixon \& Helms, 2002).

The main factor that led to the emergence, spread and rapid development of this form of corporate education is economic globalization, which stimulates the need for standardized products, services, technical infrastructure and requires organizations to provide continuous, life-long, coordinated training of personnel. Globalization also leads to increased economic competition, in which organizations can survive only due to knowledge and skills of their employees (Cunningham, 2000).

Another factor in the rapid spread of corporate universities is the struggle for human resources. The lack of skilled labor in some sectors of industry makes companies compete for attracting and retaining personnel they need. Personnel issues are dealt by corporate programs, particularly, the corporate university as the most effective of them.

In this context, the next important factor that urges corporations to establish their own corporate universities is a failure of vocational education institutions to fully meet their needs in staff training and development. An estimated $75 \%$ of the investments of organizations into corporate education are spent on customized programs and not to the standard state programs of traditional higher education institutions (Fulmer \& Gibbs, 1998).

A significant factor in the rapid spread and development of corporate universities is also a change of priorities which face them. The early universities were created mainly to integrate all types of educational activities that usually were scattered in different departments of the company, as well as to save costs and improve the quality of learning. With time, these institutions started to solve new problems, such as leadership development, improvement of recruitment procedures, employee turnover. A good example is the corporate university called Global Wireless Education Consortium, jointly established by companies working in this field worldwide. The University has partnerships with 66 universities and colleges around the world, providing knowledge and technologies, as well as compensating for the deficit of human resources in this area (Hirayama, Sho, Matsuzuka \& Kishida, 2004).

The concept of a corporate university. The main objective of corporate universities in the USA is the provision of employees with opportunities for continuous learning to ensure high work efficiency and achieve the strategic goals of the company by creating a system of effective accumulation of knowledge and system of organizational learning united by a common concept in accordance with the development strategy of the organization. Unlike the training department which decides tactical tasks, stores and transmits experience, the corporate university focuses its education policy not only on current problems, but also directs it in the future, working on anticipation of events and the implementation of the company's strategic objectives. Anticipatory nature of the implementation of continuous professional training and systematic approach to it can be considered distinctive features of educational activities provided by the corporate university.

However, despite the fact that the purpose of the corporate university is clearly stated and does not cause controversy, scientists do not have a clear, unambiguous understanding of the concept of a corporate university. In their definitions of this educational institution, researchers highlight different aspects, but most attention is focused on the following four features: the corporate university 
is a form of in-house training; it is a compositional part of the corporation; it is financed by the corporation; its goal is achieving the objectives of the corporation.

One of the earliest and most widely known definitions belongs to Jean Meister who considers the corporate university "a centralised in-house training and education facility to address the shortened shelf life of knowledge and to align training and development with business strategies" (Meister, 1998, p. 1). A comprehensive definition of corporate university was also made by Martine Plompen who, like J. Meister, emphasizes on its coordination functions and focuses on the implementation of the strategic objectives of the company, describing this educational institution as "the overall organisational umbrella for aligning and coordinating all learning for employees in order to achieve the organisation's goals" (Plompen, 2005, p. 83).

In our opinion, the corporate university should be viewed from different angles as suggested by Svitlana Sycheva (Sycheva, 2008). Conceptually corporate university is an innovative educational business model that integrates staff development with the development of the corporation and embeds learning processes in the strategic development of the company. From the standpoint of the company, corporate university is an independent structural division of the corporation that provides employee training in accordance with the strategy of its development, claiming the considerable autonomy and having its own algorithm of development. From the standpoint of corporate interests, corporate university is the most advanced form of training personnel.

Since all educational programs of institutions of this type are financed by the companies, in our view, it is equally important to consider the social aspect of the corporate university, as it is committed to fulfillment of an important social function of providing continuous professional education to employees of the corporation and delivering training to clients, customers and suppliers of the company, thus realizing their crucial need for lifelong learning. In addition, in recent decades, along with providing corporate training, these institutions also deliver general and, if necessary, remedial education of employees. In this respect an important trend in modern society can be traced - education and science, which were previously the prerogative of the state, are now becoming the responsibility of corporations, thus, on the one hand, enabling the latter to maintain competitiveness in the marketplace, and on the other - significantly reducing the governmental expenditures on education and science.

At present the following tasks of corporate universities can be singled out (Fulmer \& Gibbs, 1998):

- participation in the implementation of strategic management through professional education and training;

- assistance to candidates for senior management positions in large companies and managers of small and medium-sized companies in understanding the corporate philosophy of the company, its management strategy and stimulation of their involvement in the management of the corporation;

- formation of a high level of practical business skills;

- promotion of cooperation between the industrial sector and the scientific community.

Modes of corporate universities. Given the differences in the development strategies and needs of the organizations, the characteristics of their corporate culture and the amount of resources allocated by them for training, corporate universities of different companies in the United States differ in purpose, objectives, structural characteristics, instruction methods. At present, units of different educational levels can be called corporate universities. The educational programs they provide range from those of basic to those of post-graduate level. This may be a university in the established sense of the word, or a small training center, which calls itself a university seeking to raise its status.

Universities of large corporations in the United States are usually separate educational units with regular teaching staff, deans, accredited programs of different levels, from bachelor to doctorate. The first such institutions were called corporate colleges. They are considered the predecessors of modern corporate universities. At present, the number of corporate universities in the United States is rapidly growing (Hirayama, Sho, Matsuzuka \& Kishida, 2004). The level of vocational training in them is not lower and often even higher than that provided by traditional universities. The special value of their programs is in their practical orientation, high mobility, adaptability and compliance with requirements of modern business. 
Corporate universities have a number of distinctive features that differentiate them from traditional universities and turn them into a mechanism of rapid development and upgrading of professional competences which provides the competitiveness of companies in the marketplace (Hirayama, Sho, Matsuzuka \& Kishida, 2004):

- they offer a wider range of subjects, aiming to optimize the quality of education and training;

- they provide advanced level of education and training, the quality of knowledge and skills required from students being also high;

- they are run by corporations with an emphasis on effectiveness and efficiency;

- students have the opportunity to acquire the competencies needed in the business environment;

- academic degrees are a measure of results of professional education and training;

- they bridge the gap between education and practical business, a role that was not performed by the traditional educational system, and provide education that is useful for practical business.

Typical examples of corporate universities are Krotonvil University of General Electric Company and Motorola University. The latter has an annual budget of \$100 million, 99 offices in 21 countries, a huge permanent staff of teachers, course and program developers, translators and instructors responsible for the dissemination of knowledge within the organization. Every employee of the company holds annual training for at least 40 hours. On the other hand, the name of the corporate university can also be applied to a small Staff College, which prepares military officers in matters of administration, personnel management, etc. Other examples are Cable \& Wireless College, which offers programs in the field of telecommunications to middle and top-level managers, short courses in engineering, management and has accredited master's programs in technology in partnership with local universities (HND, MSc, MBA) (Wankel \& DeFillippi, 2002).

In this context, it is important to point out that university-industry partnership is a common practice in the US and worldwide. Social partnership in education is a recognized factor in the effective development of various sectors of education, especially vocational education. It is perceived as the interaction between educational institutions and associated market participants aimed at improving vocational education and meeting the demand for skills and competences of the workforce (Ogiienko, 2008). Scientists also believe that social partnership is a key factor of the increase in innovative performance of the economy and society as a whole (Korsun, 2016; Kornfeld \& Kara, 2015; Stigson \& Stigson, 2015).

At present, a virtual corporate university is common and widespread. An example is the Virtual University of BAE Systems (BAE Systems Virtual University). The company is engaged in the development and construction of military aircraft, ships, submarines, space systems, avionics, etc., and has its subsidiaries in the US, Europe, Australia, Asia, the Middle East. Seeking to maintain and strengthen its status as a world leader in aerospace and defense industries, the company was looking for ways of solving the problem of providing high-quality cost-effective continuous learning for over a hundred thousand of its staff worldwide. The solution was the creation of the global virtual university, which provided access to education, knowledge and skills, research results, regardless of the geographical remoteness of the region and helped to increase the efficiency and profitability of the corporation. The University offers 350 online professional courses in management, telecommunications, IT technologies. Not only staff members, but also employees of partner organizations have access to education on a contract basis. The virtual university has become a center of excellence, which provides all the needs in personnel training and development and helps in solving business problems and maintaining the competitiveness of the company. The University also makes it possible to significantly save costs on corporate training. Using e-learning allowed achieving $67 \%$ savings on education by reducing the costs on travelling, accommodation, training facilities, trainers. Overall, the company estimates its savings at half a million dollars annually (Fallon, 2005).

Veniamin Kaganov distinguishes several ways of creating corporate universities:

- a project realized through the interaction of structural components of a business organization; a structural unit in a business organization (department, service, division, center);

- faculties, departments established on the basis of educational institutions (a department of a traditional university); 
- a separate legal entity, established by a business organization; a group of educational institutions (structural units and legal entities) founded by a businesses organization.

The scientist argues that every mode of corporate university can provide necessary results depending on the stage of development of organizational learning system, but the most common and effective mode is that of a separate legal entity, because, firstly, it helps to ensure licensing and accreditation of training programs, secondly, it allows expanding the areas of corporate training and providing other services for various divisions of the company and external customers. It is also recognized by the educational and scientific community (Kaganov, 2009).

Andragogical focus of the learning process in the corporate university. As corporate education is studied in the context of adult education, the organization of the corporate training process has a clear andragogical orientation. As example, we can consider the organizational model of continuous training in the corporate university designed by Tetyana Sorokina-Ispolatova which she regards as a single cycle, comprising the following components (discrete modules) (SorokinaIspolatova, 2007):

- needs of parties concerned in the preparation of specialists;

- joint determination of the purpose of the educational program;

- integration of science, education and manufacture for the achievement of the desired learning outcomes (the purpose of the program);

- identification of ways of achieving the desired results;

- identification of ways of evaluating the results;

- determination of levels of understanding the program;

- determination of the content and form of the organization of the learning process;

- creation of corporate research and manufacturing educational environment, educational modules, teaching resources;

- diagnosis of the quality of training; determination of learning outcomes and prospects for further training (through evaluation of the quality of learning).

It should be noted that the sequence of stages of the learning process in the corporate university, determined by this researcher, is consistent with the principles of organization of the adult learning process presented in the andragogical model of Malcolm Knowles (Knowles, Holton \& Swanson, 2005). Thus, the first priority in that cycle is meeting the needs of all parties concerned (the corporations, the university, the students, the society), based on which they jointly define the goal of training, learning resources, content of the program, ways of realization of educational activities, including forms and methods of learning, create favorable learning environment, provide evaluation of results. Training is based on the use of interactive adult learning technologies, including active methods of learning and group work.

It is necessary to point out that traditional classroom learning in corporate universities in the US quickly gives way to e-learning. Internet, Intranet, groupware, online courses, web resources and others are more and more quickly developing. Using technologies as a major stimulation factor of learning is based on the creation of learning and knowledge-sharing communities among all customers inside and outside the organization, and increasingly among different organizations, and even entire industries worldwide (Wankel \& DeFillippi, 2002). Of great popularity is the so-called blended learning, which involves a combination of classroom and online training. For example, instead of classroom lectures students study the content online, and then the teacher checks and evaluates their results in class. In the corporate environment, blended learning is particularly popular and effective due to the possibility of translation of knowledge in the practice of the professional settings.

Conclusions. The results of the research give grounds for the following conclusions: corporate training plays a leading role in the successful operation of US companies and is a factor of their competitiveness and efficiency; corporate university as an advanced form of organizational training emerged in response to the challenges of the information society and the global economy, increased competition in the market, the failure of the traditional institutions of professional education to meet the needs of the modern economy for highly qualified employees; modern corporate university is a system of organizational development and personnel training, united with a common concept and methodology, inseparably linked and coordinated with the strategies of the organization; 
main functions of the corporate university are training of company employees of various levels, knowledge management, formation of common corporate values, corporate culture development, promotion of innovation.

Since organizations have different needs and development strategies, corporate universities of different companies in the United States differ in purpose, objectives, structural characteristics, methods of instruction. The learning process in the corporate university has andragogical focus and is characterized by extensive use of e-learning technologies.

Promising directions for further research are the study of corporate university curriculums, comparative educational analysis of the functioning of corporate universities in the US and Europe.

\section{References:}

Cross, J. (2011). A model of workplace learning. Retrieved February 20, 2016, from http://www.internettime.com/2011/03/a-model-of-workplace-learning/

Cunningham, S. (2000). The business of borderless education. Canberra: Evaluations and Investigations Programme, Higher Education Division, Dept. of Education, Training and Youth Affair.

Fallon, J. (2005). BAE Systems Virtual University: e-learning in action. Development and Learning in Organizations, 19(4), 11-13. http://dx.doi.org/10.1108/14777280510606538

Fulmer, R. \& Gibbs, P. (1998). Lifelong Learning at the Corporate University. Career Development International, 3(5), 177-184. http://dx.doi.org/10.1108/13620439810229389

Hirayama, M., Sho, R., Matsuzuka, Y., \& Kishida, M. (2004). Research on corporate universities: JILPT research report No 8. Retrieved December 22, 2015, from: http://www.jil.go.jp/english/reports/documents/jilpt-research/no8.pdf

Kaganov, V. S. (2009). Korporativnoe obuchenie i konkurentosposobnost' predprinimatel'skih struktur: monografija [Corporate training and competitiveness of enterprises: a monograph]. Moscow, Russia: Market DS.

Knowles, M. S., Holton, E. F., \& Swanson, R. A. (2005). The adult learner: the definitive classic in adult education and human resource development (6th ed.). Burlington, MA: Elsevier, Inc. http://dx.doi.org/10.4324/9780080481913

Korablinova, I. A. \& Stepanenko, Y. V. (2014). Rol korporaty vnogo navchannya u formuvanni kompetencij infokomunikacijny`x kompanij [The role of corporate education in shaping competencies in information and communication companies]. Naukovi praci Donecz`kogo nacional’nogo texnichnogo universy`tetu. Sery`ya: ekonomika, $5,64-71$.

Kornfeld, B. J., \& Kara, S. (2015). Industry-university collaboration in sustainable manufacturing. 22nd CIRP Conference on life cycle engineering, 29, 8 - 12. http://dx.doi.org/10.1016/j.procir.2015.02.207

Korsun, G. O. (2016). Yevropejs`ky`j dosvid reorganizaciyi nacional`ny`x sy`stem vy`shhoyi osvity` [European experience of reorganization of national systems of higher education]. Novitni osvitni texnologiyi: mizhnarodny`j dosvid: XI mizhnar. nauk.-prakt. konf., $52-53$.

Lytovchenko, I. (2015). Origins and formation of corporate education in the USA. Comparative professional pedagogy, 5(3), 53-57.

Meister, J. C. (1998). Corporate Universities: Lessons in Building a World-Class Work Force. New York:McGraw-Hill.

Nasibullin, J. N. (2011). Korporativnoe obuchenie kak faktor povyshenija intellektual'nogo potenciala personala organizacii [Corporate training as factor in increasing the intellectual potential of the organization's personnel]. Retrieved December 11, 2015, from: http://ifets.ieee.org/russian/depository/ v13_i2/html/3.html

Nixon, J. C., \& Helms, M. M. (2002). Corporate universities vs. higher education institutions. Industrial and Commercial Training, 34(4), 144 - 150. http://dx.doi.org/10.1108/00197850210429129

Ogiienko, O. I. (2008). Tendenciyi rozvy`tku osvity`dorosly`x u skandy`navs`ky`x krayinax: monografiya [Trends in adult education in the Nordic countries: monograph]. Sumy, Ukraine: Ellada-S.

Petrjakov, P. A., \& Pevzner, M. N. (2009). Korporativnoe obuchenie personala kak strategija razvitija organizacii [Corporate training as strategy for development of the organization]. Chelovek i obrazovanie, 4, $16-20$.

Plompen, M. (2005). Innovative corporate learning: excellent management development practice in Europe. Houndmills, Basingstoke, Hampshire; New York: Palgrave Macmillan. http://dx.doi.org/10.1057/9780230288799

Sorokina-Ispolatova, T. V. (2007). Nepreryvnaja podgotovka pedagoga professional'nogo obuchenija $v$ korporativnom universitete: teorija, praktika, innovacii: monografija [Continuous training of teacher of vocational training in the corporate university: theory, practice, innovation: a monograph]. Moscow, Russia: MGIU.

Stigson, B., \& Stigson, P. (2015). A future resource and pollution constrained world - an agenda for a new partnership between business, governments and academia. Technological Forecasting and Social Change, 98, 255 - 259. http://dx.doi.org/10.1016/j.techfore.2015.05.010

Sycheva, S.M. (2008). Uslovija i faktory sozdanija korporativnogo universiteta [Conditions and factors of creating a corporate university]. Vestnik universiteta, 9(1), 31 - 37.

Wankel, C., \& DeFillippi, B. (2002). Rethinking Management Education for the 21st Century. New York: Information Age Press. Received: 10.03 .2016 Accepted: 27.03.2016 